ALAN SAMSON, a lecturer at Massey University's School of Journalism, was a staff reporter and deputy chief reporter at The Dominion for nearly 20 years.

\section{A century tailor-made for remembrance}

The Dom: A century of news, edited by Karl du Fresne. Wellington: The Dominion Post, 2007. 120 pp. ISBN 9780473124366

\section{T ET'S BE BLUNT. Despite management spin and the time-} line claims of this centenary publication, Wellington-based newspaper the Dominion did not merge with its sister publication The Evening Post in the big news media shake-up of 2002.

That was the year when, in a shroud of secrecy but as a surprise to no one (apart, perhaps, for the timing), Wellington's afternoon paper the Evening Post gave in to everfalling circulation figures and closed. The morning paper the Dominion, imaginatively renamed the Dominion Post, briefly attempted to carry its sister publication's renown for local news via a special metro section,

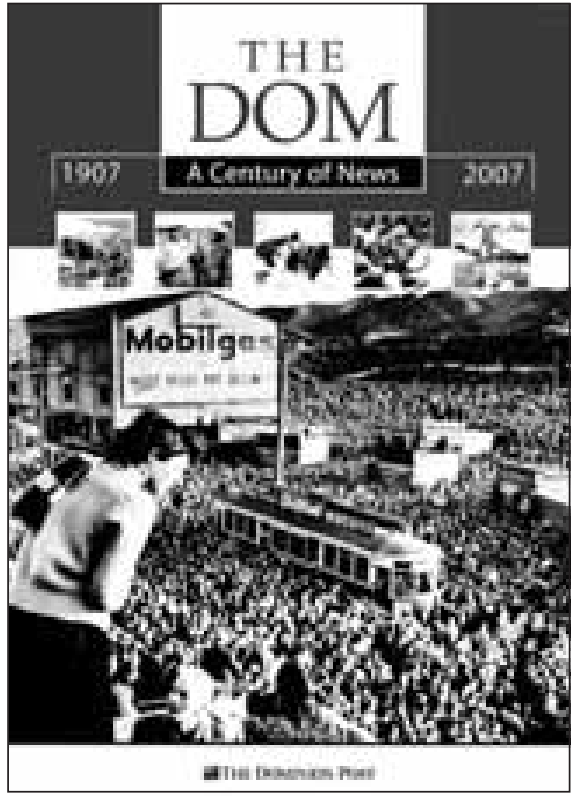

then reverted. Five years later and, apart from the figure-head, Dominion Post has almost disappeared from the language. The conversation on the bus, once again, is have you read this morning's Dom?

The long-anticipated centenary book, edited by former Dominion editor Karl du Fresne, was therefore not only aptly named, The Dom: A century of news, but was an appropriate and timely commemoration. The paper was first published on Dominion Day, 26 September 1907, and the events that made up the 100 years following of the life and times of Wellington and Wellingtonians, were worthy of a tome. 
Let me start with some praise. It's almost axiomatic that news organisation histories will be turgid journals of record. Forget the excitement of the riots, the rugby tests, the marching off to wars; do expect screeds on the introduction of computers and obscure accounting transactions. Whatever your feelings about the sometimes controversial opinions expressed elsewhere in du Fresne's columns, his work can never be accused of being boring.

For dull, try Seven Days a week: The story of Independent Newspapers Limited (Verry, 1985); The Press 1861-1961: The story of a newspaper (O'Neill, 1963); or Dateline-NZPA: The New Zealand Press Association 1880-1980 (Sanders, 1979). The Dom: A century of news does not fall into the trap. One clanger and a few peculiar omissions aside, du Fresne has done a good job in working out the themes, issues and events that have captured the attention of hundreds of thousands.

The newspaper's Dominion Day starting date, the end of New Zealand's status as a British colony, was tailor-made for remembrance. What a powerful start to re-run a first editorial on independence and freedom of the press, one that could serve as a spur for present-day practitioners:
If it is the duty of every live man to do good work in the world, that responsibility rests especially on the journalist, because of his exceptional opportunities, powers and professions...the journalist has one client, one patient, one flock - that is to say, the whole community, and nothing should stand in the way of his highminded and devoted service of that one common interest. He should beware of all entangling alliancespolitical, social, commercial—which may limit or embarrass such service. (pp. 6-7)

Du Fresne does even better as he records early events and issues warts-and-all, including an editorial that supported Prime MinisterJosephWard'scalltopreserve New Zealand as the home of white society. A particularly pejorative editorial on the 1951 waterfront strike begins: 'If anything is needed to convince the people of New Zealand that there exists in this countryatype of person whoisamenace toa society....' (p. 47).

Many of the historical snapshots and examples of old reporter prose make delightful reading. The breathless reporting of a 1907 fire in Parliament, for example, includes:

When one passed out of the blinding reek and the darkness of the entrance hall, where great throbbing snakes 
of hose-unseen, but felt by one's feet - crawled through the splashing water, and when one passed into the library, it was a place of profound peace. (p. 15)

Much of the content that follows, from the 1915 landing of Anzac troops at Gallipoli to the 'Battle of Molesworth St' during the 1981 Springbok tour, comprises exquisite finger bowls of memory to be dipped into.

Saving us from the mistake of seeing the past as golden days of reporting, a chapter written by 1960s' editor WP Reeves reminds us:

The news gathering was thorough without being enterprising. Exposés there were not. The writing was always good but the gray columns were dreary. (p. 43)

It falls to Reeves too to remind us of the ominous 1964 take-over bid of Baron Thomson of Fleet:

The board, a collection of fine old and old-fashioned gentlemen, was outraged at Lord Thomson's audacity. How dare he! The directors wrapped their skirts tightly about them and shouted Rape! (p. 43)

Reeves also usefully recalls the period of ownership that followed by a chap called Rupert Murdoch:
It was hard going for someone of Murdoch's drive and impatience. He found New Zealanders trapped in a 1930s time-warp with restrictions thwarting his enterprise at every turn. The Dominion's beleaguered masters doddered and dithered when he wanted a deal struck now... (p. 44)

This account confirms what other editors have spoken about informally: that Murdoch directives were few and far between and that he rarely if ever attempted to interfere with policy. It was interesting to be reminded, though, that it was he who was the driving force behind turning the paper into a tabloid, an ill-fated, short-lived innovation. Murdoch is described as a charming man but one who was hard to get along with, unable to be reasoned with once his mind was made up.

While there is much to enthuse about in this book, there are serious shortcomings. Most glaring-my 'clanger' - is that the chapters end at 1995 . Why? The book does mention more recent events, investigative reporter Philip Kitchin's breaking of the Louise Nicholas rape story, for instance (see pages 214-218).

But such mentions are almost afterthoughts. With some events, only half the story is told. Du Fresne reports the Press Council's uphold of a complaint about a sexualised picture 
of Prime Minister Helen Clark in the embrace of her husband, for example, but is seemingly unaware of the staff subterfuge that brought the photograph to national attention.

Other big events are strangely ignored. Drawing from my own reporting on the newspaper, I wonder at the dearth of mention of the 1987 Fiji coup and the 1990 Aramoana killing rampage. Both were significant events for the paper. In the first instance, this reviewer and photographer Simon Townsley were twice arrested at gunpoint; in the second, there were intensely interesting ethical issues to be wrestled with after a reporter in Wellington was enjoined to ring besieged Aramoana houses while the gunman was at large. The millennium Dom issue, which carried the paper's proclamation of its two 'New Zealanders of the Century'-Edmund Hillary and Ernest Rutherford-is ignored. So too is the incredible cover of the release into French custody of Rainbow Warrior conspirators Alain Mafart and Dominique Prieur, in which the newspaper staked out Whenuapai airport to confirm the filing of a flight path, publishing, for the first and possibly last time, a 3.05am edition. And what about the newspaper's characters, most notably_-pre-computers — of the old reading room?
Many chapters are once-overlightly, as evidenced by those on women and photographers. The chapter on the former omits numerous superb characters, though separate sections cover noted journalists and authors Robin Hyde and Christine Cole Catley. The chapter on photography is entirely an account of just one man, the admittedly impressive Barry Durrant. Perhaps reflecting du Fresne's era of influence, it as if the last generation of reporters and photographers fitting into the century produced no-one at all of note.

Unfortunately, it is on the shortfalls, that this book may be judged. It is an enthusiastic and easily read romp that at times is a great deal of fun. Thanks for the memories of endearing prison escaper George Wilder. Thanks, too, for reminders of the female journalists who deliciously spoofed assistant editor Frank Haden's prejudices about feminists. Haden called feminists 'bearded ladies' so, with some crude prosthetics, the journalists sprouted chin hair. (Speaking of Haden, where was mention of The Thoughts of Chairman Frank, the famous compilation of his nightly rants against...everyone?)

Ultimately, this book is no more than that romp, and an uneven one at that. So much more could have been 
drawn from histories and interviews. On a newspaper that has produced more than its share of great characters, The Dom book had the potential to be stunning. The inevitable impression is that a capable but busy du Fresne, went for his information to a select few. Or was it that, faced with an impossible deadline, he simply ran out of time and energy?

\section{References}

O'Neill, R.B. (Ed.). (1963). The Press 1861-1961: The story of a newspaper. Christchurch: Christchurch Press Company.

Sanders, J. (1979). Dateline-NZPA:

The New Zealand Press Association 1880-1980. Auckland: Wilson \& Horton.

Verry, L. (1985). Seven days a week:

The story of Independent Newspapers Limited.

Wellington: Independent Newspapers Limited.

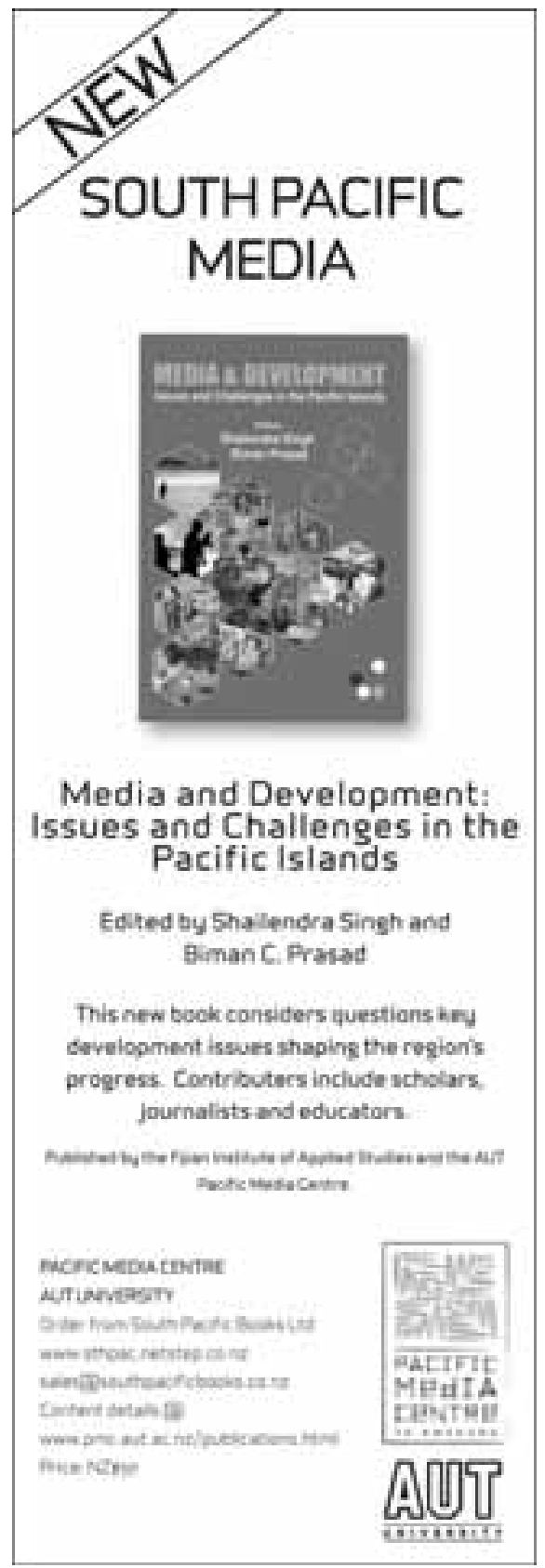

